\title{
PERAN SEKRETARIS DALAM MENANGANI PERJALANAN \\ DINAS PIMPINAN PADA PT. DWI ANUGERAH ABADI
}

\author{
Oleh: Desilia Purnama Dewi SE, MM \& \\ Catherine Indah Lestari
}

\begin{abstract}
Abstrak
Salah satu tugas sekretaris dalam melaksanakan instruksi adalah melakukan persiapan perjalanan dinas pimpinan, karena perjalanan dinas merupakan salah satu aktivitas organisasi atau perusahaan yang sering dilakukan pimpinan. Agar perjalanan dinas dapat berjalan secara efektif dan efisien, maka perlu dilakukan penjadwalan dan pengaturan pada perjalanan dinas tersebut, sehingga pekerjaan pimpinan tidak terbengkalai hanya karena kesalahan dalam menyusun jadwal atau tidak adanya jadwal yang digunakan sebagai acuan pelaksanaan perjalanan dinas.

Mengatur dan menyiapkan perjalanan dinas pimpinan meliputi,mempersiapkan segala sesuatu, mulai dari dokumen yang dibutuhkan pimpinandalam perjalanannya, konfirmasi tiket dan hotel, pembuatan jadwal perjalanan,sampai segala sesuatu yang dapat menunjang keberhasilan dan kenyamanan pimpinan dalam perjalanan dinasnya.
\end{abstract}

\section{Kata Kunci : Peran Sekretaris Dalam Menangani Perjalanan Dinas Pimpinan}

\section{PENDAHULUAN}

Peran seorang sekretaris bukan hanya sebagai salah satu karyawan dalam sebuah perusahaan, melainkan sebagai faktor penting yang mendukung kelancaran tugas-tugas pimpinan karena sebagian tugas sekretaris adalah berkaitan erat dengan pimpinan. Sekretaris adalah seorang pembantu dari seorang kepala atau pimpinan yang menerima pendiktean, menyiapkan surat-menyurat, menerima tamu, memeriksa, atau mengingatkan pimpinannya mengenai kewajibannya yang resmi atau perjanjiannya dan melakukan banyak kewajiban lainnya yang berhubungan guna meningkatkan efektivitas dari pimpinannya mengenai kewajiban lainnya yang berhubungan untuk meningkatkan efektivitas pimpinannya.(Ramon, 2005).

Perjalanan dinas adalah sebuah kegiatan perjalanan yang dilakukan untuk mewakili sebuah lembaga atau perusahaan, dengan maksud dan tujuan tertentu, yang dibiayai oleh lembaga atau perusahaan. Dengan berbagai keperluan, perjalanan dinas ini perlu dilakukan. Karena persiapan yang begitu rumit, dibutuhkan seseorang yang membantu menangani 
Salah satu tugas sekretaris dalam melaksanakan instruksi adalah melakukan persiapan perjalanan dinas pimpinan, karena perjalanan dinas merupakan salah satu aktivitas organisasi atau perusahaan yang sering dilakukan pimpinan. Agar perjalanan dinas dapat berjalan secara efektif dan efisien, maka perlu dilakukan penjadwalan dan pengaturan pada perjalanan dinas tersebut, sehingga pekerjaan pimpinan tidak terbengkalai hanya karena kesalahan dalam menyusun jadwal atau tidak adanya jadwal yang digunakan sebagai acuan pelaksanaan perjalanan dinas.

Mengatur dan menyiapkan perjalanan dinas pimpinan meliputi,mempersiapkan segala sesuatu, mulai dari dokumen yang dibutuhkan pimpinandalam perjalanannya, konfirmasi tiket dan hotel, pembuatan jadwal perjalanan,sampai segala sesuatu yang dapat menunjang keberhasilan dan kenyamanan pimpinan dalam perjalanan dinasnya.

\section{Kata Kunci : Peran Sekretaris Dalam Menangani Perjalanan Dinas Pimpinan}

\section{PENDAHULUAN}

Peran seorang sekretaris bukan hanya sebagai salah satu karyawan dalam sebuah perusahaan, melainkan sebagai faktor penting yang mendukung kelancaran tugas-tugas pimpinan karena sebagian tugas sekretaris adalah berkaitan erat dengan pimpinan. Sekretaris adalah seorang pembantu dari seorang kepala atau pimpinan yang menerima pendiktean, menyiapkan surat-menyurat, menerima tamu, memeriksa, atau mengingatkan pimpinannya mengenai kewajibannya yang resmi atau perjanjiannya dan melakukan banyak kewajiban lainnya yang berhubungan guna meningkatkan efektivitas dari pimpinannya mengenai kewajiban lainnya yang berhubungan untuk meningkatkan efektivitas pimpinannya.(Ramon, 2005).

Perjalanan dinas adalah sebuah kegiatan perjalanan yang dilakukan untuk mewakili sebuah lembaga atau perusahaan, dengan maksud dan tujuan tertentu, yang dibiayai oleh lembaga atau perusahaan. Dengan berbagai keperluan, perjalanan dinas ini perlu dilakukan. Karena persiapan yang begitu rumit, dibutuhkan seseorang yang membantu menangani persiapannya. Sekretaris yang memiliki kegiatan dalam hal kesekretariatan dituntut untuk mampu mempersiapkan kelengkapan perjalanan dinas meliputi dokumen perjalanan dinas. 
Perjalanan dinas pimpinan dapat dibedakan berdasarkan klasifikasi tujuan, sarana transportasi yang digunakan, lama waktunya, dan wilayah negara tujuan. Perjalanan dinas pimpinan berdasarkan tujuannya antara lain dapat dibedakan menjadi perjalanan dinas pimpinan untuk pelaksanaan pengawasan di kantor cabang atau perusahaan cabang, seminar, diklat, tender, janji temu, pertemuan/rapat panjajakan kerja sama, menghadiri acara seremonial, ataupun kegiatan sosial.

Perjalanan dinas pimpinan berdasarkan sarana transportasi yang digunakan dapat dibedaka menjadi perjalanan dinas lewat darat, udara, dan laut. Perjalanan dinas berdasarkan lamanya waktu dapat dibedakan menjadi perjalanan dinas dalam satu hari dan perjalanan dinas lebih dari satu hari, sedangkan perjalanan dinas dalam negeri dan perjalanan dinas ke luar negeri.

Mengatur dan menyiapkan perjalanan dinas pimpinan meliputi,mempersiapkan segala sesuatu, mulai dari dokumen yang dibutuhkan pimpinandalam perjalanannya, konfirmasi tiket dan hotel, pembuatan jadwal perjalanan,sampai segala sesuatu yang dapat menunjang keberhasilan dan kenyamanan pimpinan dalam perjalanan dinasnya.

PT Dwi Anugerah Abadi melakukan kegiatan perjalanan dinas pimpinan yang dibantu oleh seorang sekretaris dalam menjalankan tugas rutinnya. Sekretaris menjalankan segala tugas, termasuk menangani perjalanan dinas pimpinan. Seorang sekretaris ikut berperan terhadap kesuksesan perjalanan dinas pimpinanya. Dan sangat berpengaruh pada kinerja perusahaan dalam proses meningkatkan kerja sama dan mendukung perkembangan perusahaan dalam segala bidang.

\section{PENGERTIAN SEKRETARIS}

Peran seorang sekrertaris bukan hanya sebagai salah satu karyawan dalam sebuah perusahaan, melainkan sebagai faktor penting yang mendukung kelancaran tugas-tugas pimpinan karena sebagian tugas sekretaris adalah berkaitan erat dengan pimpinan. Sekretaris adalah seorang pembantu dari seorang kepala atau pimpinan yang menerima pendiktean, menyiapkan surat-menyurat, menerima tamu, memeriksa, atau mengingatkan pimpinannya mengenai kewajibannya yang resmi atau perjanjiannya dan melakukan banyak kewajiban lainnya yang berhubungan guna meningkatkan efektivitas dari pimpinannya mengenai kewajiban lainnya yang berhubungan untuk meningkatkan efektivitas pimpinannya. (Ramon, 2005). 
Menurut (Drs The Liang Gie, 2006) Pengertian sekretaris adalah seseorang petugas yang pekerjaannya menyelenggarakan urusan surat-menyurat termasuk menyiapkan bagi seorang pejabat penting atau organisasi.

\section{JENIS-JENIS SEKRETARIS}

Sekretaris memiliki ruang lingkup pekerjaan yang sangat luas. Karena luasnya ruang lingkup pekerjaan yang menentukan tugas-tugasnya, seorang sekretaris dibedakan menjadi beberapa jenis. Menurut Ursula Ernawati dalam bukunya Pedoman Lengkap Kesekretariatan untuk Sekretaris dan Calon Sekretaris (2004), jenis sekretaris dapat dikelompokkan berdasarkan:

1. Berdasarkan luas lingkup tanggung jawab
a. Sekretaris Organisasi
b. Sekretaris Pimpinan (Private Secretary)
c. Sekretaris Pribadi (Personal Secretary)

2. Berdasarkan kemampuan kerja dan pengalaman kerja
a. Sekretaris Junior
b. Sekretaris Senior

3. Berdasarkan Spesialisasi dalam Pekerjaan
a. The Legal Secretary (sekretaris yang bekonsentrasi dalam bidang hukum)
b. The Medical Secretary (sekretaris yang berkonsentrasi dalam bidangmedis)
c. The Technical Secretary (sekretaris yang berkonsentrasi dalam bidang teknik tertentu)
d. The Accounting Secretary (sekretaris yang berkonsentrasi dalam bidang akuntansi) 


\section{TUGAS SEKRETARIS}

Seorang sekretaris dalam pekerjaannya sehari-hari, tidak hanya membantu pimpinan menyelesaikan tugasnya, namun ia juga dibebani oleh tugas-tugas kesekretariatannya. Seperti dalam hal korespondensi, kearsipan, dan penyelenggaraan rapat. Semua itu juga merupakan tugas sekretaris. Tugas sekretaris dalam arti sempit adalah sebagai orang yang dipercaya oleh pimpinan untuk menyimpan rahasia pimpinan. Sedangkan tugas sekretaris dalam arti luas adalah pelaksanaan tugas-tugas yang bersifat membantu manajer atau pimpinan untuk menjalankan roda organisasi, lembaga, maupun kantor. (Saiman, 2002).

Menurut H. W Fowler dan F. G Fowler yang dikutip oleh Nani Nuraeni dalam buku Sekretaris Professional mengemukakan bahwa sekretaris adalah orang yang bekerja pada orang lain untuk membantu dalam korespondensi, pekerjaan tulis, mendapatkan informasi dan masalah-masalah lainnya. Pegawai yang ditunjuk oleh masyarakat atau perusahaan atau perserikatan untuk melakukan korespondensi, memelihara warkat-warkat, terutama yang berurusan dengan perusahaannya. Menteri yang mengepalai kantor pemerintah, menteri di Amerika Serikat dan Vatikan menjelasakan bahwa sekretaris dibanding dengan posisi lain, sekretaris termasuk karyawan yang memiliki multi tugas, di antaranya :

1. Menurut wewenangnya.

a. Tugas rutin. Meliputi pengetikan, making call, menerima tamu, korespondensi, filling, surat menyurat.

b. Tugas instruksi. Meliputi penyusunan jadwal perjalanan, making appointment, pengaturan keuangan, persiapan dan penyelenggaraan rapat, arrange schedule.

c. Tugas kreatif meliputi pembuatan formulir telepon, dokumentasi, mengirim ucapan kepada klien, mengatur ruang kantor pimpinan.

2. Menurut jenis tugasnya.

a. Tugas administrasi meliputi surat menyurat, pembuatan laporan, filling.

b. Tugas resepsionis meliputi making call, melayani tamu, menyusul jadwal pertemuan pimpinan.

c. Tugas sosial meliputi mengatur rumah tangga kantor, mengirim ucapan selamat kepada relasi, mempersiapkan respsi/jamuan acara resmi kantor. 
d. Tugas insidentil meliputi mempersiapkan rapat, mempersiapkan pidato, presentasi, dan mempersiapkan perjalanan dinas pimpinan.

\section{PENGERTIAN PERJALANAN DINAS}

Perjalanan dinas adalah sebuah kegiatan perjalanan yang dilakukan untuk mewakili sebuah lembaga atau perusahaan, dengan maksud dan tujuan tertentu, yang dibiayai oleh lembaga atau perusahaan. Dengan berbagai keperluan, perjalanan dinas ini perlu dilakukan. Karena persiapan yang begitu rumit, dibutuhkan seseorang yang membantu menangani persiapannya. Sekretaris yang memiliki kegiatan dalam hal kesekretariatan dituntut untuk mampu mempersiapkan kelengkapan perjalanan dinas meliputi dokumen perjalanan dinas.

Perjalanan dinas adalah perjalanan ke luar tempat kedudukan yang jaraknya sekurangkurangnya 5 (lima) kilometer dari batas kota, yang dilakukan untuk kepentingan perusahaan, dapat dilaksanakan dengan menggunakan kendaraan sendiri maupun kendaraan pribadi yang biayanya ditanggung oleh perusahaan yang menuggaskan.

Sedangkan pendapat lain yang dikemukakan oleh Drs. Ignatius Wursanto. Perjalanan dinas adalah perjalanan yang dilakukan oleh seorang karyawan atau pegawai suatu lembaga atau perusahaan yang berkaitan dengan tugas pekerjaan kedinasan.

Dari beberapa pendapat di atas, dapat disimpulkan bahwa perjalanan dinas adalah perjalanan yang dilakukan oleh pegawai atau karyawan suatu lembaga atau perusahaan yang berkaitan dengan keperluan dinas, perjalanan dinas meliputi perjalanan dinas dalam kota dan luar kota, maupun luar negeri yang biayanya ditanggung oleh perusahaan dan dilakukan selama beberapa waktu.

\section{MACAM-MACAM PERJALANAN DINAS}

Perjalanan dinas pimpinan dapat dibedakan berdasarkan klasifikasi tujuan, sarana transportasi yang digunakan, lama waktunya, dan wilayah negara tujuan. Perjalanan dinas pimpinan berdasarkan tujuannya antara lain dapat dibedakan menjadi perjalanan dinas pimpinan untuk pelaksanaan pengawasan di kantor cabang atau perusahaan cabang, seminar, diklat, tender, janji temu, pertemuan/rapat panjajakan kerja sama, menghadiri acara seremonial, ataupun kegiatan sosial. Perjalanan dinas pimpinan berdasarkan sarana transportasi yang digunakan dapat dibedaka menjadi perjalanan dinas lewat darat, udara, 
dan laut. Perjalanan dinas berdasarkan lamanya waktu dapat dibedakan menjadi perjalanan dinas dalam satu hari dan perjalanan dinas lebih dari satu hari, sedangkan perjalanan dinas dalam negeri dan perjalanan dinas ke luar negeri.

Dari semua klasifikasi tersebut membawa implikasi yang berbeda terhadap tugastugas yang harus dilakukan sekretaris, terutama mengenai akomodasi dan dokumendokumen yang harus disiapkan sekretaris, baik dokumen perjalanan itu sendiri maupun dokumen yang berhubungan langsung dengan tujuan perjalanan dinas pimpinan. Berikut akan dijelaskan beberapa macam perjalanan dinas pimpinan yang akan membawa konsekuensi terhadap tugas-tugas yang harus dilakukan oleh sekretaris.

\section{MACAM-MACAM DOKUMEN PERJALANAN (TRAVEL DOCUMENTS)}

Sekretaris hendaknya mempersiapkan berkas-berkas, peraturan-peraturan yang berhubungan dengan masalah yang akan dirundingkan, surat-surat penting, akta-akta, brosur, dll. Jika pimpinan mengadakan perjalanan dinas untuk mengikuti konferensi, seminar, rapat dinas ataupun yang sejenisnya, sekretaris harus sudah mengadakan persiapan jauh hari sebelumnya. Persiapan itu terdiri atas materi-materi, naskah dan bahan yang akan menjadi topik pembicaraan sesuai dengan acara atau agenda yang sudah ditetapkan.

Selanjutnya, bila pimpinan harus melakukan perjalanan dinas ke luar negeri, perlu menambahkan persiapan untuk mengurus paspor dan sebagainya. Dokumen perjalanan ke luar negeri yang harus dipersiapkan oleh sekretaris antara lain meliputi :

1. Surat tugas atau surat perintah jalan

Untuk dapat melakukan perjalanan dinas, pegawai atau pimpinan yang bersangkutan harus mendapat surat perintah perjalanan dinas (SPPD) dari pejabat yang berwenang.

2. Paspor

Adalah dokumen perjalanan yang diberikan kepada seorang warga negara, yang diberi izin untuk meninggalkan negaranya dan untuk pergi ke negara tertentu. Di Indonesia, salah satu persyaratan yang harus dipenuhi oleh seseorang yang akan pergi ke luar negeri adalah pengesahan dari pemerintah, melalui Depertemen Kehakiman yang berupa exit permit yaitu surat izin meninggalkan negara. Surat tersebut dapat diperolah di kantor imigrasi setempat. 
3. Visa

Yaitu tanda izin yang dicap pada lebaran-lembaran paspor untuk mengunjungi suatu negara tertentu dalam waktu tertentu.

4. Yellow card (kartu kesehatan)

Merupakan kartu yang dikeluarkan oleh dinas kesehatan untuk diberikan kepada warga negara yang akan ke luar negeri.

5. Fiskal

Adalah pajak yang harus dikeluarkan oleh warga negara yang akan berangkat ke luar negeri, dipenuhi di lapangan udara pada saat keberangkatan.

\section{LANGKAH-LANGKAH MENGATUR PERJALANAN DINAS}

Seorang sekretaris yang handal, umumnya dipercayai pimpinannya untuk mengatur perjalanan dinas pimpinan. Tugas dan tanggung jawab sekretaris tidak ringan. Ia harus mempersiapkan segala sesuatu, mulai dari dokumen yang dibutuhkan pimpinan dalam perjalanannya.

Menurut Dra. Eny Winarni dalam artikelnya yang berjudul Mengatur Perjalanan Bisnis menjelaskan ada beberapa hal yang harus dilakukan oleh sekretaris sehubungan dengan penyelenggaraan perjalanan dinas, adapun yang harus dipersiapkan oleh sekretaris adalah :

1. Merencanakan Perjalanan

2. Mempersiapkan Daftar Perjalanan

3. Mempersiapkan Dokumen Perjalanan

4. Mempersiapkan Transportasi.

\section{KESIMPULAN}

Perjalanan dinas yang efektif merupakan hal yang baik untuk pencapaian tujuan perusahaan dalam suatu menejemen yang baik. Peran seorang sekretaris adalah mengatur jadwal perjalanan dinas dengan baik dan sesuai prosedur perusahaan, serta membantu mempersiapkan dan mengelola perjalanan dinas sehingga pimpinan bisa berkonsentrasi pada kepemimpinannya. 


\section{DAFTAR PUSTAKA}

Ernawati, Perjalanan Dinas Pimpinan, Jakarta:Depdikbud, 2001.

Barthos, Bashir, Dinas Pimpinan, Jakarta:Bumi Aksara, 2003.

Boedi Martono, Sistem Perjalanan Dinas Pimpinan, Jakarta:Pusataka Sinar Harapan, 2001.

Martono, E., Kepemimpinan dan Pengertian Perjalanan Dinas Pimpinan, Jakarta:Karya Utama, 2004.

Sedarmayanti, Perjalanan Bisnis Pimpinan, Bandung, 2003.

Adya Brata_Perjalanan Dinas Pimpinan.Blogspot.com / 2006 